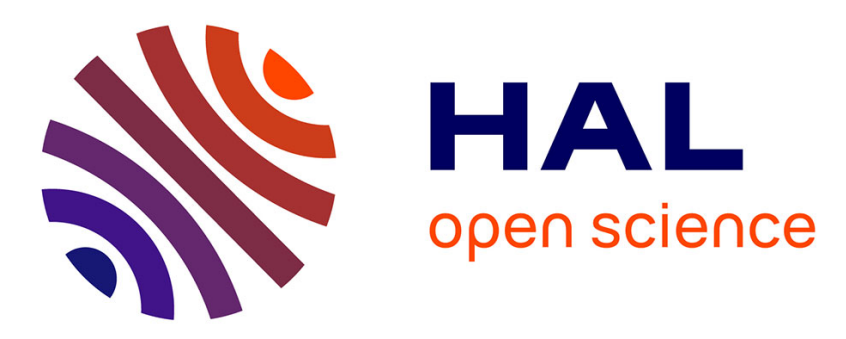

\title{
Determinants of the efficiency of regional innovation systems
}

Michael Fritsch, Viktor Slavtchev

\section{To cite this version:}

Michael Fritsch, Viktor Slavtchev. Determinants of the efficiency of regional innovation systems. Regional Studies, 2008, pp.1. 10.1080/00343400802251494 . hal-00514716

\section{HAL Id: hal-00514716 https://hal.science/hal-00514716}

Submitted on 3 Sep 2010

HAL is a multi-disciplinary open access archive for the deposit and dissemination of scientific research documents, whether they are published or not. The documents may come from teaching and research institutions in France or abroad, or from public or private research centers.
L'archive ouverte pluridisciplinaire HAL, est destinée au dépôt et à la diffusion de documents scientifiques de niveau recherche, publiés ou non, émanant des établissements d'enseignement et de recherche français ou étrangers, des laboratoires publics ou privés. 


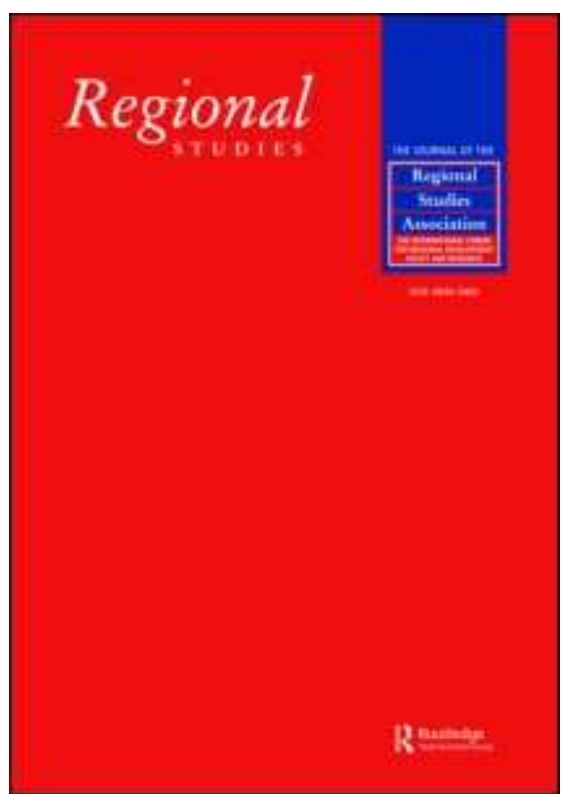

\section{Determinants of the efficiency of regional innovation systems}

\begin{tabular}{|r|l|}
\hline Journal: & Regional Studies \\
\hline Manuscript ID: & CRES-2007-0279.R1 \\
\hline Manuscript Type: & Main Section \\
\hline JEL codes: & $\begin{array}{l}\text { O18 - Regional, Urban, and Rural Analyses < O1 - Economic } \\
\text { Development < O - Economic Development, Technological Change, } \\
\text { and Growth, O31 - Innovation and Invention: Processes and } \\
\text { Incentives < O3 - Technological Change|Research and Development } \\
\text { < - Economic Development, Technological Change, and Growth, } \\
\text { R12 - Size and Spatial Distributions of Regional Economic Activity }< \\
\text { R1 - General Regional Economics < R - Urban, Rural, and Regional } \\
\text { Economics }\end{array}$ \\
\hline Keywords: & $\begin{array}{l}\text { Technical efficiency, Innovation, Patents, Knowledge, Spillovers, } \\
\text { Regional Innovation System }\end{array}$ \\
\hline
\end{tabular}

\section{SCHOLARONE Manuscripts}




\title{
Determinants of the efficiency of regional innovation systems
}

\author{
Michael Fritsch ${ }^{\ddagger *} \&$ Viktor Slavtchev ${ }^{\ddagger}$ \\ First received: September 2007 \\ Accepted: March 2008
}

\begin{abstract}
This paper analyzes differences in the efficiency of regional innovation systems (RIS). Alternative measures for the efficiency of RIS based on the concept of a knowledge production function are discussed. The empirical findings suggest that spillovers from within the private sector as well as from universities and other public research institutions have a positive effect on the efficiency of private sector R\&D. It is particularly the intensity of interactions between private and public sector R\&D that increases the efficiency. We find that regions dominated by large establishments tend to be less efficient than regions with a lower average establishment size.
\end{abstract}

\section{Zusammenfassung}

Wir analysieren Unterschiede in der Effizienz regionaler Innovationssysteme (RIS). Zunächst werden alternative Maße für die Effizienz von RIS diskutiert, die auf dem Konzept der Wissensproduktionsfunktion aufbauen. Die empirischen Ergebnisse deuten darauf hin, dass sowohl Spillover aus dem privaten Sektor als auch von Hochschulen und anderen öffentlichen Forschungseinrichtungen die Effizienz privater F\&E-Aktivitäten positiv beeinflussen. Insbesondere die Intensität der Interaktion zwischen öffentlichen Einrichtungen und dem Privatsektor führt zu hoher Effizienz. Regionen, die durch Großbetriebe dominiert sind, weisen tendenziell eine geringere Effizienz der Innovationsaktivitäten auf als Regionen mit einer geringeren durchschnittlichen Betriebsgröße.

JEL-classification: O31, O18, R12

Keywords: $\quad$ Regional innovation system, technical efficiency, patents.

‡ Friedrich-Schiller-University Jena, School of Economics and Business Administration, Carl-Zeiss-Str. 3, 07743 Jena, Germany. 
$\underline{\text { Les déterminants de l'efficience des systèmes d'innovation régionaux. }}$

* German Institute for Economic Research (DIW) Berlin, and Max Planck Institute of Economics, Jena, Germany.

E-mail: $\underline{\text { m.fritsch@uni-jena.de; } \text { viktor.slavtchev@uni-jena.de }}$

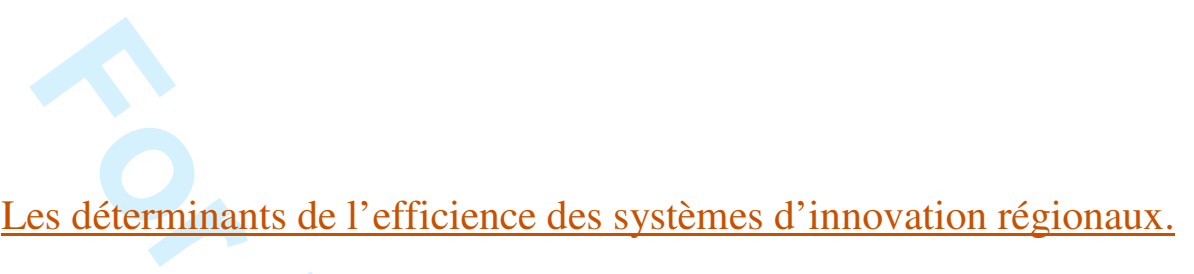

Fritsch \& Slavtchev

Cet article cherche à analyser les écarts de'efficience des systèmes d'innovation régionaux (SIR). On discute des autres mesures de l'efficience des SIR fondées sur la notion d'une fonction de production de la connaissance. Les résultats empiriques laissent supposer que les retombées provenant de l'intérieur du secteur privé aussi bien que des universités et des autres établissements publics de recherche ont un effet positif sur l'efficience de la $\mathrm{R}$ et $\mathrm{D}$ du secteur privé. C'est notamment l'intensité de l'interaction entre la $\mathrm{R}$ et $\mathrm{D}$ du secteur privé et celle du secteur public qui augmente $\underline{\text { l'efficience. Il s'avère que les régions où prédominent les grands établissements ont }}$ 
tendance à être moins efficients que ne le sont les régions où la taille des établissements est inférieure à la moyenne.

\section{Systèmes d'innovation régionaux / Efficience technique / Brevets}

Classement JEL: O31; O18; R12

\section{Determinantes de la eficiencia de los sistemas de innovación regional}

\section{$\underline{\text { Michael Fritsch \& Viktor Slavtchev }}$}

$\underline{\text { En este artículo analizamos las diferencias en la eficiencia de los sistemas }}$ $\underline{\text { regionales de innovación (SRI). Asimismo estudiamos medidas alternativas para la }}$ eficiencia de los SRI en función del concepto de una función de producción del conocimiento. Los resultados empíricos indican que los desbordamientos desde dentro del sector privado así como de las universidades y otras instituciones de 
investigación públicas tienen un efecto positivo en la eficiencia de I+D del sector privado. Es especialmente la intensidad de las interacciones entre la I+D del sector privado y público la que aumenta la eficiencia. Observamos que las regiones dominadas por grandes establecimientos tienden a ser menos eficientes que las regiones con un tamaño medio más bajo de establecimientos.

Keywords:

$\underline{\text { Sistema de innovación regional }}$

$\underline{\text { Eficacia técnica }}$

$\underline{\text { Patentes }}$

JEL-classification: O31, O18, R12 


\section{Introduction}

Inventions and innovations are not evenly distributed in space but tend to be clustered in certain locations (FELDMAN, 1994; PACI and USAI, 1999, 2000; MORENO, PACI and USAI, 2005). Possible reasons for this phenomenon include regional differences in the availability and the quality of local inputs, as well as geographically bounded knowledge spillovers (GREUNZ, 2003; FRITSCH and SLAVTCHEV, 2007, 2008). Another reason may be that locations differ with regard to the "quality" or the "efficiency" of regional innovation systems (RIS), leading to different levels of innovative output even if the inputs are identical in quantitative as well as in qualitative terms. The available empirical evidence for such differences in RIS efficiency is, however, sparse and not at all convincing. We still know only very little about the conditions that are conducive or unfavorable for innovation activity and how policy could help improve the functioning of RIS. Moreover, it is not clear how to assess the efficiency of regional innovation processes.

This paper elaborates on the determinants of RIS efficiency. We first introduce two different measures for RIS efficiency, both of which are based on the concept of a knowledge production function (Section 2), and describe the spatial distribution of efficiency among German planning regions (Section 3). Section 4 discusses the possible determinants of RIS efficiency. The results of multivariate regression analyses of the impact of different factors 
on RIS efficiency are presented in Section 5. Finally, we draw conclusions for further research (Section 6).

\section{Assessing the efficiency of RIS}

Our understanding of RIS ${ }^{1}$ efficiency corresponds to the concept of technical efficiency as introduced by FARRELL (1957). Farrell regards an economic unit as being inefficient if it fails to generate the maximum feasible output from a given set of inputs. Reasons for technical inefficiency can be manifold and comprise all sorts of mismanagement, such as inappropriate work organization, improper use of technology, as well as X-inefficiency, as defined in LEIBENSTEIN's (1966) seminal work. Applying this definition to the concept of a regional innovation system means that a region is technically efficient if it is able to produce the possible maximum of innovative output from a given amount of innovative input. Accordingly, a RIS is regarded as technically inefficient if its output falls below the maximum possible value.

In this paper, we use the concept of a knowledge production function (KPF) for analyzing the relationship between input and output of the innovation process, which is essential for assessing the technical efficiency of regional innovation systems. The basic hypothesis behind the KPF is that inventions do not simply occur out of "thin air," but result predominantly from R\&D activities. According to GRILICHES (1979) and JAFFE (1989), who 
assume a Cobb-Douglas type function for the relation between input and output, the KPF can be expressed as

(1) $\quad Y_{i}=A_{i} X_{i}^{\beta_{i}}$.

$Y_{i}$ denotes the innovative output of a region $i$, and $X_{i}$ is a set of inputs.

$A_{i}=\alpha e^{-u_{i}}$ is an inefficiency parameter, with $\alpha$ as a constant term, which is common for all regions, while $u_{i} \in[0 ; 1]$ denotes the technical inefficiency of a certain region $i$.

Our measure for innovative output is based on the number of disclosed regional patent applications in the years 1995 to 2000 . These data were provided by the German Patent Office (Deutsches Patent- und Markenamt), as published in GREIF and SCHMIEDL (2002). A patent application indicates that an invention has been made that extends the existing knowledge pool. However, there are several limitations to using the number of patents as a measure of innovative output. First, patents are granted for an invention, but that invention is not necessarily transformed into an innovation, i.e., a new product or production technology. Second, patents are for products, rather than processes (COHEN, NELSON and WALSH 2000). Third, because there are other ways besides patenting to appropriate the returns of successful R\&D 
activities (cf. COHEN, NELSON and WALSH 2002), the number of patents may underestimate actual innovative output.

The German Patent Office provides information on the number of regional patent applications in 31 different technological fields and from three distinct sources: private companies, public research, and private persons. However, although classification of the patents into different technological fields is based on the International Patent Classification (IPC), ${ }^{2}$ the level of aggregation into technological fields does not allow assigning patent applications to $R \& D$ activities related to a specific industry or academic discipline. As this paper focuses on the efficiency of private $R \& D$, only corporate patent applications are analyzed, i.e., patent applications by public research institutions or private persons are omitted. ${ }^{3}$ The patent applications are assigned to the region where the inventor resides. ${ }^{4}$

As a proxy for input to the innovation process in the private sector, we use the number of $R \& D$ employees in this sector $(R \& D)$. This information is taken from the establishment file of the German Social Insurance Statistics (Statistik der sozialversicherungspflichtig Beschaeftigten), as described and documented by FRITSCH and BRIXY (2004). Employees are classified as working in R\&D if they have a tertiary degree in engineering or in the natural sciences. Only regional private sector R\&D employment is included as an explanatory variable in the knowledge production function; other input 
variables are omitted. The reason for this is that the number of private sector $R \& D$ employees appears to be the only factor that has a direct impact on innovative output in that sector. Knowledge spillovers from adjacent regions or spillovers from other sources, such as public research institutions, may also make a considerable contribution to the innovation process in the private sector; however, their impact is rather indirect in nature, mainly through the private sector R\&D employees. ${ }^{5}$

When relating knowledge input to innovative output, we have to assume that there is a time lag, mostly because a certain amount of time is required before R\&D activity will result in a patent. Moreover, patent applications are published anywhere from 12 to 18 months after submission, which is the amount of time the patent office needs to verify whether an application fulfils the basic preconditions for being granted a patent and to complete the patent documents (GREIF and SCHMIEDL, 2002). Therefore, a time lag between innovative inputs and output of at least two years should be assumed. ${ }^{6}$ However, because reliable data on R\&D employment in East Germany are available only from 1996 onward, we reduce the time lag between R\&D input and the patent application to a period of one year. Hence, the R\&D output for the $1997-2000$ period is related to R\&D input between 1996 and 1999. This appears justified because there are no great fluctuations of either innovation input or innovation output during these years and the differences between the estimated parameters of a KPF with a time lag of one year and with a time 
lag of two years are negligible. ${ }^{7}$ Moreover, reducing the time lag increases the number of available observations and degrees of freedom.

The spatial framework used for analysis of RIS efficiency consists of the 97 German planning regions (Raumordnungsregionen). The main advantage of using planning regions is that they are functional units that account for travel to work areas and they include at least one core city as well as its surroundings. ${ }^{8}$ This is particularly important because the patents in our database are assigned to the inventor's residence; thus, using the planning region as the unit of observation makes it more likely that the inventor will both work and live in the same region, thus avoiding the problem of having R\&D input assigned to an area different from where its output occurs (DEYLE and GRUPP, 2005). For historical reasons, the cities of Berlin, Hamburg, and Bremen are defined as planning regions even though they are not functional economic units. To avoid possible distortions, we merged these cities with adjacent planning regions (Berlin with the region of Havelland-Flaeming, Hamburg with the region of Schleswig-Holstein-South, and Bremen with Bremerhaven and Bremen-Umland). Hence, the estimation approach applied in this paper is based on observations for 93 regions over four years.

From the perspective of the KPF, there are two possible reasons why a region's innovative output is lower than the highest possible level. The first reason is due to a relatively low value of the slope parameter $\beta_{i}$, which can 
be interpreted as the marginal patent productivity or output elasticity of private sector R\&D employees. A second reason could have to do with differences in the level of the function with a given slope. Such differences reflect the various levels of $R \& D$ output with a certain input in terms of average productivity and would correspond to different values of the constant term of the function. Based on these two types of differences, we employ two approaches for assessing RIS efficiency (for further discussion, see KALIRAJAN and SHAND, 1999).

The first approach relies on the idea of regional differences in the slope of the knowledge production function. To estimate the specific productivity of each region in terms of the marginal return to $R \& D$ input, we include a binary dummy variable for each region, $D_{i}\left(D_{i}=1\right.$ if $i=i$, otherwise 0$)$, that is multiplied by the respective number of private sector R\&D employees. The constant term $A$ is assumed to be identical for all regions. Hence, Equation (1) can be rewritten as

(2) $\quad \ln \left(\right.$ Number of patents $\left.s_{i}\right)=\ln A+\sum_{i} \beta_{i} * D_{i} * \ln \left(R \& D\right.$ priv $\left._{i}\right)+\varepsilon_{i}$,

with $\beta_{i}$ as a measure of the output elasticity of private sector R\&D employment in the $i^{\text {th }}$ region $(i=1, \ldots, 93)$. Based on the estimated values for the output elasticity of private sector R\&D, we define the efficiency of a 
certain region as the quotient of the observed output of a particular region and the maximum possible value, i.e.,

$$
T E_{i}^{D E T}=\exp \left(\ln \left(\text { Number of patents } s_{i}\right)-\left(\ln A+\beta_{\max } * \ln \left(R \& D \text { priv }_{i}\right)+\varepsilon_{i}\right)\right)
$$

where $\beta_{\max }=\max _{i}\left\{\beta_{i}\right\}$ is the maximum estimated output elasticity of R\&D input. Accordingly, at least one region is assumed to be fully efficient. We label this approach "deterministic" because it implies that all deviations from the maximum value are due to inefficiency, and therefore ignores the possibility that values could be affected by measurement errors or by random disturbances. ${ }^{9}$ The output elasticity of private sector R\&D is estimated by means of a negative binomial regression technique (GREENE, 2003, 931939). Due to the relatively short length of the time series (four years), the data are pooled.

In our second approach, the produced output may fall systematically below the maximum, not because of lower output elasticities of the factors of production, but because of a lower level of the function. In this case $\beta_{i}$ is identical for all regions $\left(\beta_{i}=\beta, \forall \mathrm{i}\right)$. Thus, the knowledge production function can be expressed as

(4) Number of patents $s_{i}=\alpha R \& D$ priv $_{i}^{\beta} e^{-v_{i}} e^{u_{i}}$, 
where $v_{i}$ denotes effects of the region-specific environment on innovative output and $u_{i}$ represents the stochastic error term. The technical efficiency of a region can, therefore, be calculated as

$$
T E_{i}^{S F A}=e^{-v_{i}}
$$

Therefore, a RIS achieves its maximum feasible output if, and only if, it is fully efficient $\left(v_{i}=0\right)$. The value of $v_{i}$ provides a measure of the deviation of observed output from the possible maximum. This type of approach is called a stochastic frontier function (SFA) because it allows for stochastic disturbances. This implies that extreme values are not necessarily taken as the benchmark for the measurement of efficiency. The yearly data for the regions are pooled, and the technical efficiency is estimated as the average value per region. To separate the impact of technical inefficiency $v_{i}$ from the general stochastic effects $u_{i}$, an a priori assumption about the distribution of technical inefficiency is necessary. The general assumption in this respect is that the distribution of technical efficiency has a negative skewness (SCHMIDT and LIN, 1984), i.e., that most regions are clustered close to the efficiency frontier. Several specifications for the inefficiency term $v_{i}$ are possible: $v_{i}$ can be assumed to be independently and exponentially distributed with variance $\sigma_{v}^{2}$, or independently and half-normally $N^{+}\left(0 ; \sigma_{v}^{2}\right)$ distributed, or independently $N^{+}\left(\mu ; \sigma_{v}^{2}\right)$ distributed with a truncation point at 0 . Due to the 
fact that the choice of the distributional assumption is a priori not clear, we estimate the efficiency measure with all three alternatives in order to check the robustness of the results. Table A1 in the Appendix provides descriptive statistics of private sector R\&D input and output used to estimate RIS efficiency.

\section{The distribution of RIS efficiency}

There are considerable differences between the technical efficiency values for the German planning regions. The efficiency levels estimated by means of both approaches - the deterministic frontier function and the stochastic frontier function-show a wide spread, with the least efficient region attaining only 6.7 and 9.9 percent of the highest value (Table 1 and Figure 1). As compared to the stochastic frontier method, the deterministic approach leads to a slightly more differentiated assessment of RIS efficiency. However, the spatial distribution of the technical efficiency of RIS according to the different approaches is virtually identical. The Pearson correlation coefficients suggest almost perfect correlation between the efficiency values estimated by either approaches (Table 1).

-- Insert Table 1 here -- 
The spatial distribution of the efficiency values (Figure 1) suggests that regions with similar values of technical efficiency tend to be clustered together. Planning regions with the highest values of technical efficiency are located in the south, in the west, and in the center of the country. None of the planning regions in the north or in the east of Germany fall into this category. In particular, the values for the technical efficiency of RIS tend to be relatively high in larger, densely populated areas such as Munich, Stuttgart, Cologne, and Frankfurt. The Berlin region, which is in the middle range of efficiency ranking, is an exception in the East German innovation landscape. Regions with relatively low values for the efficiency of their innovation system are entirely located in the north and in the east. Generally, border region location appears unfavorable. Regions with moderate values of technical efficiency are found predominantly in the center of the country, separating the west from the east as well as the south from the north. This indicates that the German innovation system is spatially divided into different regimes with diverging levels of performance.

\footnotetext{
-- Insert Figure 1 here --
} 


\section{Possible determinants of RIS efficiency}

There are many factors that influence RIS efficiency. It is plausible to assume that the ability of private sector $R \& D$ employees to produce innovative output may depend on the availability and the quality of knowledge and other innovative inputs in the region. Given that innovation processes are characterized by a pronounced division of labor, ${ }^{10}$ one may expect that RIS efficiency depends on how intensely the regional knowledge base is exploited and expanded through the interaction of regional agents. RIS efficiency may, therefore, be strongly influenced by the level and the quality of interaction and exchange between different elements and the respective knowledge flows (spillovers). This interaction may be critically dependent on the availability of potential cooperation partners in the region, such as other private firms working in the same technological field, public research institutes, and suppliers of innovative inputs and services. Therefore, the density and industrial composition of the regional actors, the accessibility of the region, and the technological, industrial, and institutional infrastructure (e.g., the "networks") all may play an important role. ${ }^{11}$ The interaction between the different elements of RIS generates partly self-enforcing systemic effects that may result in specific knowledge as well as specific technologies and methods of problem solving (GERTLER, 2003), which can be 
expected to affect the workability of the system (LEYDESDORFF and FRITSCH, 2006).

We assume that the amount of knowledge spillover within the private sector is related to the number of R\&D employees in this sector. The greater the number of $R \& D$ employees, the greater the opportunity to find a suitable partner for cooperation and knowledge exchange. The indicator for knowledge spillovers within the private sector is the share of $R \& D$ employment in that sector $(R \& D)$.

The knowledge generated and accumulated by universities may constitute a basic precondition for private sector R\&D activity (JAFFE, 1989). However, since universities are nonprofit organizations, they can hardly market the results of their own $R \& D$ in terms of new products or technologies. For this reason, their knowledge has to spill over to other actors (e.g., private companies) in order to become commercially effective. There are various ways such knowledge transfers can occur (see VARGA, 1998, for an overview). In particular, channels for transfer of academic knowledge, such as R\&D cooperation with private sector firms or the provision of innovation-related services, play a major role in private sector innovative activity (MANSFIELD and LEE, 1996; COHEN, NELSON, and WALSH 2002). However, the impact of universities on private sector firm innovation may vary considerably depending on the quality of a university's research 
and the intensity with which the university interacts with the firms (e.g., Feldman and Desrochers, 2003; MANSFIELD and LeE, 1996; Fritsch and SLAVTCHEV, 2007, 2008). To test the impact of universities on private sector performance we introduce the amount of third-party funds the universities obtain from private firms (TPF-PRIV). In general, third-party funds can be regarded as an indicator of the amount and quality of the university's research because allocation of third-party funds is usually based on some competitive procedure and is, therefore, largely dependent on the quality of the research conducted. According to HORNBOSTEL (2001), there is a distinct correspondence between indicators that are based on third-party funds and bibliometric indicators for high-quality research, such as SCI publications. Funds from private sector firms, in particular, can be regarded as compensation for academic R\&D or other services. Hence, these revenues are an appropriate indication of the relevance of academic research to commercial applications, as well as of the intensity of university-industry linkages, which may lead to pronounced knowledge spillovers (FRITSCH and SLAVTCHEV, 2007, 2008).

Although we have no detailed information about the location of the private firms that cooperate with universities, one can assume that, in most cases, universities and cooperating private firms are located in the same planning region (FRITSCH and SCHWIRTEN, 1999). ${ }^{12}$ To avoid possible scale effects of large universities, which are likely to attract larger amounts of third- 
party funds from private firms, we use the average amount of third-party funds from private sector firms per university professor.

Nonuniversity public research institutions, such as the Max-PlanckSociety (MPG) and the Fraunhofer-Society (FhG), may also have a positive effect on the technical efficiency of private sector $R \& D$ employees. Unfortunately, we do not have information about the third-party funds of these institutes; thus, we introduce the regional number of institutes in our analysis.

As far as a technology is unique in the sense that the transfer and the application of knowledge pertinent to it requires specific skills or a specific common language, the strength of knowledge spillovers depends critically on the degree of technological similarity between the parties (JAFFE, 1986; NADIRI, 1993). Therefore, we introduce the technological proximity between public and private sector $R \& D$ as a measure of correspondence and potential interplay of the regional actors in the innovation process (PROXTECH). The technological proximity between public and private sector $R \& D$ is measured as the degree of congruence between the technological fields of the patent output of public research institutions $\left(P A T_{A C A D}\right)$ and private sector firms $\left(P A T_{P R I V}\right):^{13}$ 
(6) $\quad \operatorname{PROXTECH}_{i}=\frac{P A T_{A C A D i} * P A T_{P R I V i}}{\left|P A T_{A C A D i}\right| *\left|P A T_{P R I V i}\right|}$.

This index can assume values between 0 and 1 . The larger the value, the closer the technological proximity between public and private sector R\&D, and the greater the possibility for cooperation and knowledge spillovers.

The service sector may provide important support for R\&D activity in diverse ways, such as counseling, technical services, provision of venture capital, etc. This is particularly true of knowledge-intensive business services, which in some cases have even been associated with the emergence of high-tech regions such as Silicon Valley and Route 128 (SAXENIAN, 1985; DORFMAN, 1983). According to FELDMAN and FLORIDA (1994), the presence of business services indicates a relatively well-developed infrastructure that may be beneficial for innovation. One could, therefore, expect a positive impact of the share of the regional service sector (SERVICES) on RIS efficiency. On the other hand, a high share of the service sector in the region could have a negative effect due to the relatively low propensity of this sector to apply for and be granted patents (GREIF and POTKOWIK, 1990; BODE, 2004).

Population density (number of inhabitants in the region per squared kilometer, POPDEN) is a measure not only of the effects of urbanization 
economies on RIS performance, but can also be regarded as a catch-all variable for diverse types of unobserved region-specific influences. The literature suggests that high population density should be conducive to innovation activity because it is related to intensive contacts and cooperation (for an overview, see FELDMAN, 2000; FRITSCH, 2000). Therefore, one could expect a positive sign for this variable. The average number of employees per establishment (SIZE) is intended to capture the effects of establishment size. According to a number of previous empirical studies, the number of patents per employee is higher in smaller firms than in large firms (see COHEN and KLEPPER, 1996, for a discussion); therefore, a negative sign could be expected. Two binary dummy variables are employed to capture additional unobserved effects of location in West Germany (WEST) and on the periphery (PERIPHERY). We expect a positive sign for location in West Germany due to the generally weaker performance of the economy in the eastern part of the country, which is obvious from the assessment of RIS efficiency shown in Figure 1. Assuming that a location on the periphery (border) is unfavorable for innovation activity due to relatively great geographical distance from other actors, we expect a negative sign for this variable.

As the propensity to patent the results of R\&D may differ between industries (e.g., some industries might find more profitable ways to appropriate the returns of R\&D than patenting), RIS efficiency may be subject 
to industry-specific effects. To control for the impact of regional specialization in certain industries having a relatively high level of patenting, we include the share of employees in transportation engineering (TRANSPORT), in electrical engineering (ELECTRICAL), in measurement engineering and optics (OPTICS), and in chemistry (including biochemistry) (CHEMICALS) into our model. According to GREIF and SCHMIEDL (2002), these are the technological fields with the highest share of patent applications in Germany. ${ }^{14}$ Table 2 provides a summary of the definitions and data sources of the variables. Descriptive statistics for the variables are provided in Table 3. Table A2 in the Appendix sets out the correlations between the variables.

-- Insert Table 2 here --

-- Insert Table 3 here --

To estimate the model, we transform the dependent, as well as the independent, variables into log-values. An important advantage of logging 
both sides of the equation is that the estimated coefficients can be regarded as elasticities that can be directly compared with each other. To assess the presence and the importance of interdependences between the geographical units of investigation, we carried out several diagnostic tests (Moran's I, LMError, robust LM-Error, LM-Lag and robust LM-Lag) for such spatial dependences. These tests indicate the presence of spatial dependence that takes the form of a spatial autoregressive process in the error term. Therefore, we apply a spatial error model

(7) $Y=X \beta+\varepsilon$,

where $\varepsilon=\lambda W \varepsilon+\mu, \lambda$ denotes the spatial autoregressive parameter, $\mu$ denotes a homoscedastic and uncorrelated error term, and $W$ rowstandardized spatial weights matrix based on a first-order contiguity (ANSELIN, 1988; ANSELIN and BERA, 1998). Additionally, a robust variancecovariance estimator is applied (WHITE, 1980).

\section{Empirical results}

The impact of different determinants on RIS efficiency under the deterministic and stochastic frontier approaches are reported in Table 4. With respect to the stochastic frontier approach, there are three different assumptions about the distribution of the inefficiency term: half-normal distribution, normal 
distribution with a truncation point at zero, and exponential distribution. However, since the efficiency measures obtained with all three assumptions are almost perfectly correlated (see Table 1), we compare the deterministic frontier approach with only one version of the stochastic frontier approach, that of the half-normal distribution. ${ }^{15}$

The share of private sector R\&D employment $(R \& D)$ has a pronounced positive impact on RIS efficiency. The estimated coefficient provides clear evidence for the relevance of scale economies, i.e., an increase in the share of private sector R\&D employment at a certain location can lead to higher efficiency of innovation processes. Obviously, high R\&D intensity at a certain location may stimulate knowledge spillover between actors. However, if more measures for regional specialization in certain industries are included, the impact of the share of R\&D employment becomes slightly weaker. This is particularly the case for the share of regional employment in electrical engineering ( $E L E C T R I C A L)$. The average amount of third-party funds from private sector sources per university professor (TPF-PRIV) has a positive impact on RIS efficiency, suggesting that the intensity of university-industry linkages, as indicated by the money paid by private firms for university R\&D, is conducive to regional innovation activity. Substituting TPF-PRIV by other university-related indicators, such as the number of academic personnel, shows hardly any statistically significant impact for the respective variable and results in a considerable reduction of the log-likelihood of the model. 
These results clearly confirm previous findings for the role of academic research on innovation activity in Germany (FRITSCH and SLAVTCHEV, 2007, 2008).

A positive impact can also be found for nonuniversity public research establishments as indicated by the number of research institutes of the MaxPlanck Society (MPG) and of the Fraunhofer Society (FhG). These results suggest that there are knowledge spillovers from both types of researchbasic research conducted at the Max-Planck-Institutes and more applied research as typically carried out by the institutes of the Fraunhofer Societywhich increase the technical efficiency of a RIS. ${ }^{16}$ Regions with a high efficiency of innovation activity are characterized by pronounced technological proximity between public and private $R \& D$, as measured by the PROXTECH-variable. ${ }^{17} \mathrm{~A}$ possible explanation for this finding is that the knowledge exchange between the two sectors becomes more likely as public and private research operate in similar technological fields.

-- Insert Table 4 here -- 
The positive coefficient for population density (POPDEN) indicates the presence of urbanization economies. This suggests that densely populated regions provide a variety of opportunities for interaction and rich supplies of inputs, as well as a comprehensive physical and institutional infrastructure that is advantageous for innovation activity.

The coefficient for the share of service sector employment (SERVICE) indicates a negative impact on RIS efficiency, meaning that despite their supporting function, resources allocated to the service sector are less efficient in terms of patenting than in manufacturing. This confirms previous results of BODE (2004), who found a negative impact of servicemanufacturing ratio on regional innovation output. As indicated by the significantly negative coefficient for average firm size $(S I Z E)$, patenting efficiency tends to be lower in regions characterized by a high share of large establishments. This result is in line with other studies, which find that the number of patents per unit of R\&D input is higher in smaller firms than in larger ones (ACS and AUDRETSCH, 1990; COHEN and KLEPPER, 1996). According to the positive and highly significant coefficient of the dummy variable for location in West Germany (WEST), innovation activities in regions located in the western part of the country are more efficient than those in East Germany. This result suggests that there are still considerable differences in the efficiency of the innovative process in the two parts of the country even after reunification in 1990 . There are at least two possible 
explanations for this difference. First, a relatively pronounced industrial monostructure ${ }^{18}$ and a concentration on less innovative industries may cause a technological shortfall in East Germany. Second, such an efficiency gap may result from a relatively low convergence speed due to slow learning and path-dependent innovation processes. The estimated coefficient for the dummy variable for regions located on the periphery of Germany is not statistically significant.

The local presence of industries with relatively high patent intensity has a positive impact on RIS efficiency (at the 10 percent significance level) only with respect to electrical engineering (ELECTRICAL). Nevertheless, controlling for industry structure in the region appears important for at least two reasons. First, introducing the share of the electrical engineering industry significantly increases the goodness of fit (squared correlation, log likelihood) of the model. Second, tThe parameter of spatial dependence $\lambda$, that is otherwise significant, becomes insignificant if a control for the size of this industry in the region is included.

\section{Summary and conclusions}

The objective of this paper is to provide an answer to the question of what factors can explain differences in RIS efficiency. For this purpose, we first introduce two measures for RIS efficiency based on the concept of a KPF. 
These approaches for assessing RIS efficiency lead to virtually identical results. In particular, the spatial distribution of efficiency estimates turns out to be very similar under both approaches.

We found a number of factors that have an effect on RIS efficiency. Our results suggest that knowledge spillovers within the private sector as well as those that occur between public research institutions (universities as well as nonuniversity research institutes) and actors in the private sector have a positive impact on private sector innovation activity. The presence of universities and other public research institutes and their interaction with private sector firms also proves to be conducive. This effect is particularly strong when the technological fields of research pursued in public research institutes correspond to those of innovation activity in the private sector. Population density has a positive effect on innovation performance, indicating that $R \& D$ activity is more productive in agglomerations than in rural areas. The negative effects of the employment share in the service sector and of average establishment size correspond with the relatively low patent intensity in the service industries and in larger firms, which has been found in other empirical studies. RIS in West Germany are considerably more efficient than those in the eastern part of the country, even after controlling for all other influences that have a significant effect. There is no indication for lower efficiency of innovation activity in regions located at the periphery of the country. All in all, our results are consistent with the view that RIS 
performance is strongly influenced by the level and the quality of interaction and exchange between their different elements. To put it differently, a pronounced division of innovative labor leads to relatively high efficiency.

Our results raise some important questions for further research. One of the most important of these has to do with how knowledge transfers occur between different actors. A policy that aims at improving RIS efficiency should be able to identify the most efficient means of knowledge transfer and how such transfers can be stimulated. What stimulates knowledge spillover and the division of innovative labor between the elements of a RIS? What are the impediments in this respect? Lastly, regarding the role of industrial specialization for innovation, more information about the role of the industrial structure of a region for the efficiency of innovation activity would be helpful in order to design appropriate policy. The low efficiency of RIS in East Germany indicates that there may be a considerable degree of path dependency that shapes performance in this part of the country. This implies that it may take a fairly long time until a policy aimed at improving RIS performance produces significant results. 


\section{References}

Acs Z. J. and AudRETSCH D. B. (1990) Innovation and Small Firms. Cambridge University Press, Cambridge (Mass.).

Acs Z. J., ANSELIN L. and VARgA A. (2002) Patents and innovation counts as measures of regional production of new knowledge, Research Policy 31, 1069-1085.

ANSELIN L. (1988) Spatial Econometrics: Methods and Models. Kluwer Academic, Boston.

ANSELIN L. and BERA A. K. (1998) Spatial Dependence in Linear Models with an Introduction to Spatial Econometrics, in ULLAH A. and GILES D. E. (Eds) Handbook of Applied Economic Statistics, pp. 237-290. Dekker, New York.

Arora A. and Gambardella A. (1994) The changing technology of technical change: General and abstract knowledge and the division of innovative labour, Research Policy 23, 523-532.

Arora A. and Gambardella A. (1998) Evolution of industry structure in the chemical industry, in ARORA A., LANDAu R. and RosenBERG N. (Eds) Chemicals and Long Term Economic Growth: Insights from the Chemical Industry, pp. 379-414. John Wiley \& Sons, New York. 
Arora A., Gambardella A. and Rullani E. (1997) Division of labour and the locus of inventive activity, Journal of Management and Governance 1, $123-140$.

Arora A., Fosfuri A. and Gambardella A. (2001) Specialized technology suppliers, international spillovers and investment: Evidence from the chemical industry, Journal of Development Economics 65, 31-54.

ASHEIM B. and GERTLER M. S. (2005) The geography of innovation: Regional innovation systems, in Fagerberg J., Mowery D. C. and Nelson R. R. (Eds) The Oxford Handbook of Innovation, pp. 291-317. Oxford University Press, Oxford.

Beise M. and Stahl H. (1999) Public research and industrial innovations in Germany, Research Policy 28, 397-422.

BODE E. (2004) The spatial pattern of localized R\&D spillovers: An empirical investigation for Germany, Journal of Economic Geography 4, 43-64.

Bundesamt fuer BauWesen und Raumordnung - BBR (2003) Aktuelle Daten zur Entwicklung der Staedte, Kreise und Gemeinden. Band 17. BBR, Bonn.

BUNDESMINISTERIUM FUER BILDUNG UND FORSCHUNG - BMBF (2004) Bundesbericht Forschung 2004. BMBF, Bonn. 
CAMAGNI R. (1991) Local "milieu”, uncertainty and innovation networks: Toward a new dynamic theory of economic space, in CAMAGNI R. (Ed.) Innovation Networks: Spatial Perspectives, pp. 121-144. Belhaven Press, London.

Cockburn I., Henderson R., Orsenigo L. and Pisano G. P. (1999) Pharmaceuticals and biotechnology, in MOWERY D. C. (Ed) US Industry in 2000: Studies in Competitive Performance, pp. 363-398. National Academy Press, Washington DC.

COHEN W. M. and KLEPper S. (1996) A reprise of size and R\&D, Economic Journal 106, 925-951.

Cohen W. M., Nelson R. R. and Walsh J. P. (2000) Protecting their intellectual assets: Appropriability conditions and why U.S. manufacturing firms patent (or not), NBER Working Paper 7552.

Cohen W. M., Nelson R. R. and Walsh J. P. (2002) Links and Impacts: The influence of public research on industrial R\&D, Management Science 48, 1-23.

CoOke P., Uranga M. G. and EtxebarRia G. (1997) Regional innovation systems: Institutions and organisational dimensions, Research Policy 26, 475-491. 


\begin{abstract}
Crevoisier O. (2004) The innovative milieus approach: Toward a territorialized understanding of the economy? Economic Geography $80,367-379$.
\end{abstract}

DEYLE H.-G. and GRUPP H. (2005) Commuters and the regional assignment of innovative activities: A methodological patent study of German districts, Research Policy 34, 221-234.

DORFMAN N. S. (1983) The development of a regional high-technology economy, Research Policy 12, 299-316.

EDQUIST C. (1997) Systems of innovation approaches-Their emergence and characteristics, in EDQUIST C. (Ed.) Systems of InnovationTechnologies, Institutions and Organizations, pp. 1-40. Pinter, London.

FARRELL M. J. (1957) The measurement of productive efficiency, Journal of the Royal Statistic Society 120, 253-282.

Feldman M. P. (1994) The Geography of Innovation. Kluwer Academic Publishers, Boston.

FELDMAN M. P. (2000) Location and innovation: The new economic geography of innovation, spillovers, and agglomeration, in CLARK G. L., Feldman M. P. and GertLer M. S. (Eds) Oxford Handbook of Economic Geography, pp. 373-394. Oxford University Press, Oxford. 
Feldman M. P. and Desrochers P. (2003) Research universities and local economic development: Lessons from the history of Johns Hopkins University, Industry and Innovation 10, 5-24.

FELDMAN M. P. and FLORIDA R. (1994) The geographic sources of innovation: Technological infrastructure and product innovation in the United States, Annals of the Association of American Geographers 84, 210229.

FISCHER M. M. and VARGA A. (2003) Spatial knowledge spillovers and university research: Evidence from Austria, Annals of Regional Science 37, 303-322.

FRITSCH M. (2000) Interregional differences in R\&D activities—An empirical investigation, European Planning Studies 8, 409-427.

FRITSCH M. and BRIXY U. (2004) The establishment file of the German Social Insurance Statistics, Schmollers Jahrbuch [Journal of Applied Social Science Studies] 124, 183-190.

FRITSCH M. and SCHWIRTEN C. (1999) Enterprise-university co-operation and the role of public research institutions in regional innovation systems, Industry and Innovation 6, 69-83.

FRITSCH M. and SLAVTCHEV V. (2007) Universities and Innovation in space, Industry and Innovation 14, 201-218. 
FRITSCH M. and SLAVtCHEV V. (2008) Local Knowledge Sources, Spillovers and Innovation, Department of Economics and Business Administration, Friedrich-Schiller-University Jena, Germany, mimeo.

GERTLER M. S. (2003) Tacit knowledge and the economic geography of context, or the undefinable tacitness of being (there), Journal of Economic Geography 3, 75-99.

GRABHER G. (1993) Rediscovering the social in the economics of interfirm relations, in GrabHeR G. (Ed) The Embedded Firm-On the Socioeconomics of Industrial Networks, pp. 1-31. Routledge, London.

Greene W. H. (2003) Econometric Analysis. $5^{\text {th }}$ edition. Prentice Hall, New York.

GREIF S. and PotKoWIK G. (1990) Patente und Wirtschaftszweige. Heymann, Cologne.

Greif S. and SchmiedL D. (2002) Patentatlas Deutschland. Deutsches Patent- und Markenamt, Munich.

GREUNZ L. (2003) Geographically and technologically mediated knowledge spillovers between European regions, Annals of Regional Science 37, 657-680. 
GRILICHES Z. (1979) Issues in assessing the contribution of research and development to productivity growth, Bell Journal of Economics 10, 92116.

HoRnBOSTEL S. (2001) Third party funding of German universities. An indicator of research activity, Scientometrics 50, 523-537.

JAFFE A. B. (1986) Technological opportunity and spillovers of R\&D: Evidence from firms' patents, profits, and market value, American Economic Review 76, 984-1001.

JAFFE A. B. (1989) Real effects of academic research, American Economic Review 79, 957-970.

KaliRAjan K. P. And Shand R. T. (1999) Frontier production functions and technical efficiency measures, Journal of Economic Surveys 13, 149172.

Krugman P. (1991) Geography and Trade. MIT-Press, Cambridge (Mass.).

Leibenstein H. (1966) Allocative efficiency vs. "X-efficiency", American Economic Review 56, 392-415.

LEYDESDORFF L. and FRITSCH M. (2006) Measuring the knowledge base of regional innovation systems in Germany in terms of a triple helix dynamics, Research Policy 35, 1538-1553. 


\author{
LUNDVALL B.-A. (1992) User-producer relationships, national systems of \\ innovation and internationalisation, in LUNDVALL B.-A. (Ed) National \\ Systems of Innovation: Towards a Theory of Innovation and Interactive \\ Learning, pp. 45-67. Pinter, London.
}

MANSFIELD E. and LeE J.-Y. (1996) The modern university: Contributor to industrial innovation and recipient of industrial $R \& D$ support, Research Policy 25, 1047-1058.

MORENO R., PACI R. and USAI S. (2005) Geographical and sectoral clusters of innovation in Europe, Annals of Regional Science 39, 715-739.

NADIRI M. I. (1993) Innovations and Technological Spillovers, NBER Working Paper 4423.

Nelson R. R. (Ed) (1993) National Innovation Systems-A Comparative Analysis. Oxford University Press, New York.

PACI R. AND USAI S. (1999) Externalities, knowledge spillovers and the spatial distribution of innovation, GeoJournal 49, 381-390.

PACI R. AND USAI S. (2000) The role of specialization and diversity externalities in the agglomeration of innovative activities, Rivista Italiana degli Economisti 2, 237-268.

Porter M. (1998) Clusters and the new economics of competition, Harvard Business Review 76, 77-90. 
Pyke F., Becattini G. and Sengenberger W. (Eds) (1990) Industrial Districts and Inter-Firm Co-operation in Italy. International Institute for Labor Studies, Geneva.

RATtI R., BRAmanti A. and Gordon R. (1997) The Dynamics of Innovative Regions: The GREMI approach. Aldershot, Ashgate.

ROMER P. M. (1994) The origins of endogenous growth, Journal of Economic Perspectives 8, 2-22.

RONDE P. and HUSSLER C. (2005) Innovation in regions: What does really matter, Research Policy 34, 1150-1172.

SAXENIAN A. (1985) Silicon Valley and Route 128: Regional prototypes or historical exceptions? in Castells, M. (Ed.) High-Technology, Space and Society. Sage, Beverly Hills.

Schartinger D., Schibany A. and GASSLER H. (2001) Interactive relations between universities and firms: Empirical evidence for Austria, Journal of Technology Transfer 26, 255-268.

SCHMIDT P. and LIN T.-F. (1984) Simple tests of alternative specifications in stochastic frontier models, Journal of Econometrics 24, 349-361.

VARGA A. (1998) University Research and Regional Innovation: A Spatial Econometric Analysis of Academic Technology Transfers. Springer, New York. 
WHITE H. (1980): A heteroskedasticity-consistent covariace matrix estimator and a direct test for heteroskedasticity, Econometrica 48, 817-838. 
Table 1: Descriptive statistics for distribution of technical efficiency in German planning regions

\begin{tabular}{|c|c|c|c|c|c|c|c|c|c|}
\hline No. & \multirow[t]{2}{*}{$\overline{\text { Variable }}$} & \multirow[t]{2}{*}{ 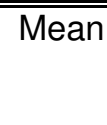 } & \multirow[t]{2}{*}{$\overline{\text { Median }}$} & \multirow[t]{2}{*}{ Min. } & \multirow[t]{2}{*}{ Max. } & \multirow[t]{2}{*}{ Std. Dev. } & \multicolumn{3}{|c|}{$\begin{array}{c}\text { Pearson correlation } \\
\text { coefficient }\end{array}$} \\
\hline & & & & & & & 1 & 0 & 3 \\
\hline 1 & $T E_{i}^{D E}$ & 0.434 & 0.452 & 0.067 & 1.000 & 0.203 & 1.000 & & \\
\hline 2 & $\mathrm{TE}_{\mathrm{i}}^{\mathrm{SF} / \mathrm{H}}$ & 0.514 & 0.558 & 0.091 & 0.920 & 44 & 0.987 & 1.000 & \\
\hline 3 & $\mathrm{TE}_{\mathrm{i}}^{\mathrm{SFA}}$ (truncated normal) & 0.539 & 0.599 & 0.097 & 0.922 & 0.249 & 0.981 & 0.999 & 1.000 \\
\hline 4 & $\mathrm{TE}_{\mathrm{i}}^{\mathrm{SFA}}$ (exponential) & 0.571 & 0.651 & 0.104 & 0.921 & 0.253 & 0.969 & 0.995 & 0.998 \\
\hline
\end{tabular}

Notes: Number of observations (regions) $=93$. 
Table 2: Definition of variables and expected sign of coefficient

\begin{tabular}{|c|c|c|}
\hline Variable & Operational definition & Expected sign \\
\hline$R \& D$ & $\begin{array}{l}\text { Share of R\&D employees in the private sector; source: } \\
\text { Social Insurance Statistics. }\end{array}$ & + \\
\hline TPF-PRIV & $\begin{array}{l}\text { Third-party funds per university professor (including } \\
\text { Fachhochschulen) in } 1,000 \text { s of Euro; source: German } \\
\text { University Statistics. }\end{array}$ & + \\
\hline MPG & $\begin{array}{l}\text { Number of institutes of the Max Planck Society; source: } \\
\text { BUNDESMINISTERIUM FUER BILDUNG UND FORSCHUNG (2004). }\end{array}$ & + \\
\hline FhG & $\begin{array}{l}\text { Number of institutes of the Fraunhofer Society; source: } \\
\text { BUNDESMINISTERIUM FUER BILDUNG UND FORSCHUNG (2004). }\end{array}$ & + \\
\hline PROXTECH & $\begin{array}{l}\text { Correspondence of the technological fields of public and } \\
\text { private sector R\&D; source: own calculation based on patent } \\
\text { statistics (GREIF and SCHMIEDL, 2002). }\end{array}$ & + \\
\hline POPDEN & $\begin{array}{l}\text { Population density; source: BUNDESAMT FUER BAUWESEN UND } \\
\text { RAUMORDNUNG - BBR. }\end{array}$ & + \\
\hline SERVICES & $\begin{array}{l}\text { Employment share in the service sector; source: Social } \\
\text { Insurance Statistics. }\end{array}$ & $+1-$ \\
\hline SIZE & $\begin{array}{l}\text { Average number of employees per establishment; source: } \\
\text { Social Insurance Statistics. }\end{array}$ & - \\
\hline WEST & Dummy for location in West Germany (yes $=1 ;$ no $=0$ ) & + \\
\hline PERIPHERY & $\begin{array}{l}\text { Dummy for location of a planning region at the border of the } \\
\text { country (yes }=1 ; n o=0 \text { ) }\end{array}$ & - \\
\hline TRANSPORT & $\begin{array}{l}\text { Employment share in transportation engineering; source: } \\
\text { Social Insurance Statistics. }\end{array}$ & + \\
\hline ELECTRICAL & $\begin{array}{l}\text { Employment share in electrical engineering; source: Social } \\
\text { Insurance Statistics. }\end{array}$ & + \\
\hline OPTICS & $\begin{array}{l}\text { Employment share in optics and measurement engineering; } \\
\text { source: Social Insurance Statistics. }\end{array}$ & + \\
\hline CHEMICALS & $\begin{array}{l}\text { Employment share in chemistry; source: Social Insurance } \\
\text { Statistics. }\end{array}$ & + \\
\hline
\end{tabular}


Table 3: Descriptive statistics for independent variables

\begin{tabular}{lrrrrr}
\hline \hline Variable & Mean & Median & Minimum & Maximum & Standard Deviation \\
\hline R\&D & 0.019 & 0.016 & 0.006 & 0.044 & 0.008 \\
TPF-PRIV & 11.062 & 7.195 & 0.000 & 97.067 & 14.735 \\
MPG & 0.860 & 0.000 & 0.000 & 12.000 & 1.839 \\
FhG & 0.849 & 0.000 & 0.000 & 10.000 & 1.763 \\
PROXTECH & 0.623 & 0.659 & 0.200 & 0.837 & 0.139 \\
SERVICES & 0.321 & 0.312 & 0.220 & 0.523 & 0.056 \\
SIZE & 13.204 & 13.308 & 8.529 & 18.266 & 1.696 \\
POPDEN & 336.990 & 180.675 & 53.425 & $3,886.292$ & 507.559 \\
TRANSPORT & 0.043 & 0.031 & 0.010 & 0.226 & 0.037 \\
ELECTRICAL & 0.035 & 0.029 & 0.004 & 0.123 & 0.023 \\
OPTICS & 0.009 & 0.005 & 0.002 & 0.055 & 0.009 \\
CHEMISTRY & 0.017 & 0.010 & 0.001 & 0.180 & 0.023 \\
\hline \hline
\end{tabular}

Notes: Number of observations (regions) $=93$. 
Table 4: Determinants of RIS efficiency

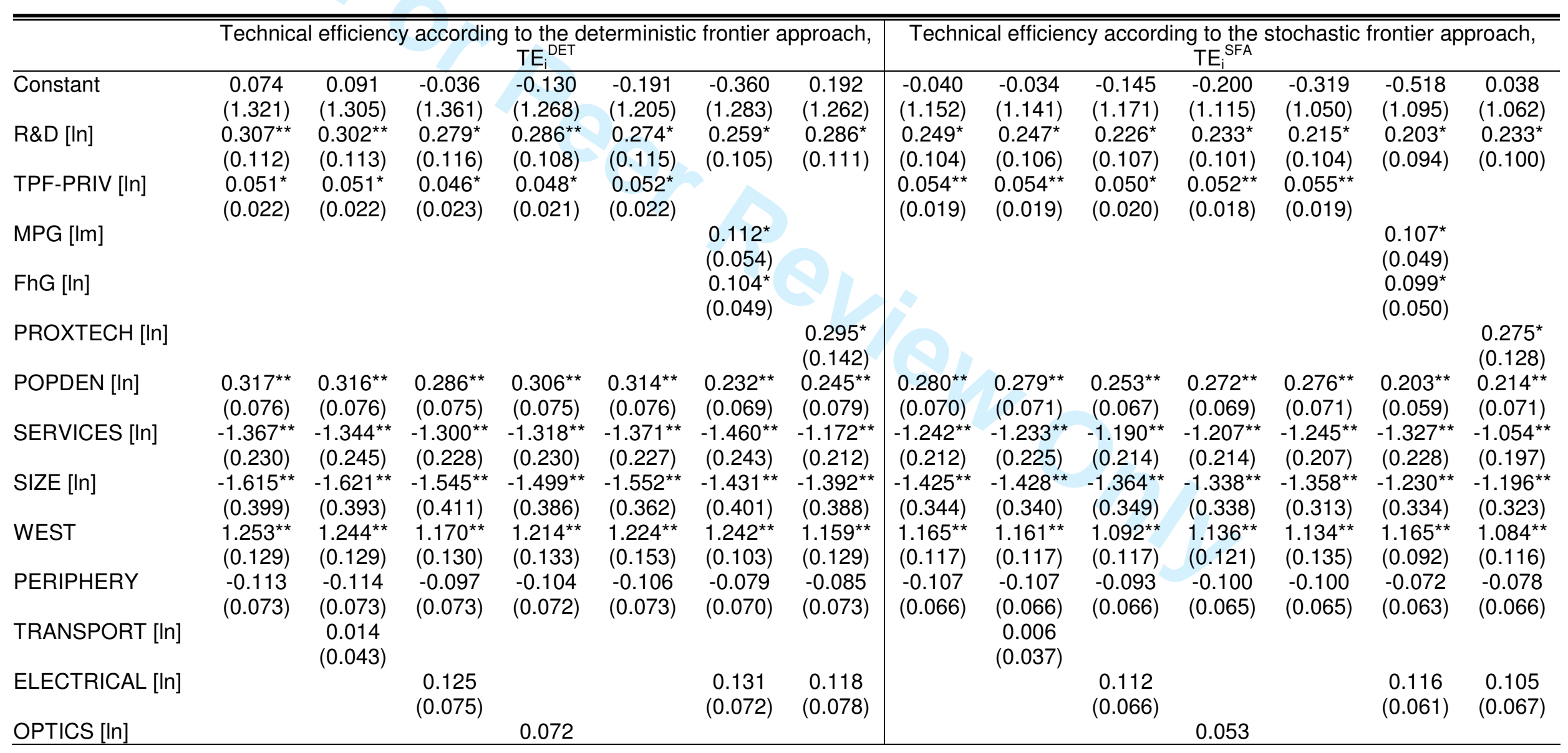




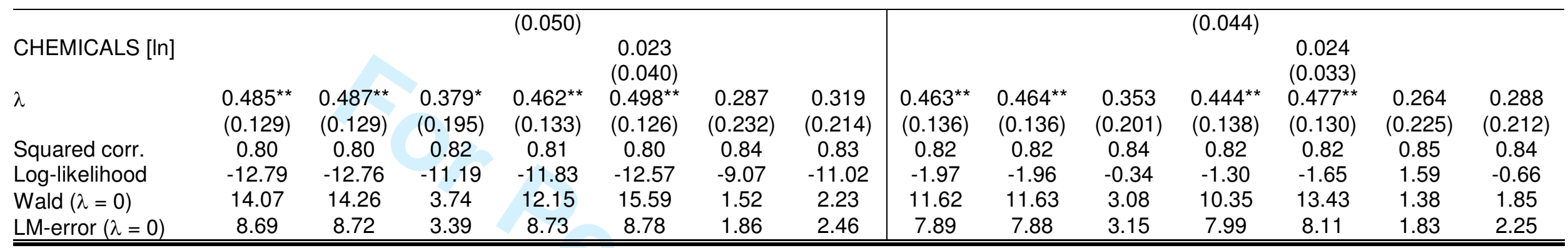

Notes: Robust standard errors in parentheses; ${ }^{*}$ significant at $5 \%$ level; ${ }^{* *}$ significant at $1 \%$ level. Critical value for the Wald test-statistic and LM-error is 3.48 ( $p=$ $0.05)$; spatial weights are row-standardized: $\mathrm{W}$ is $1^{\text {st }}$ order contiguity matrix. Number of observations (regions) $=93$. 


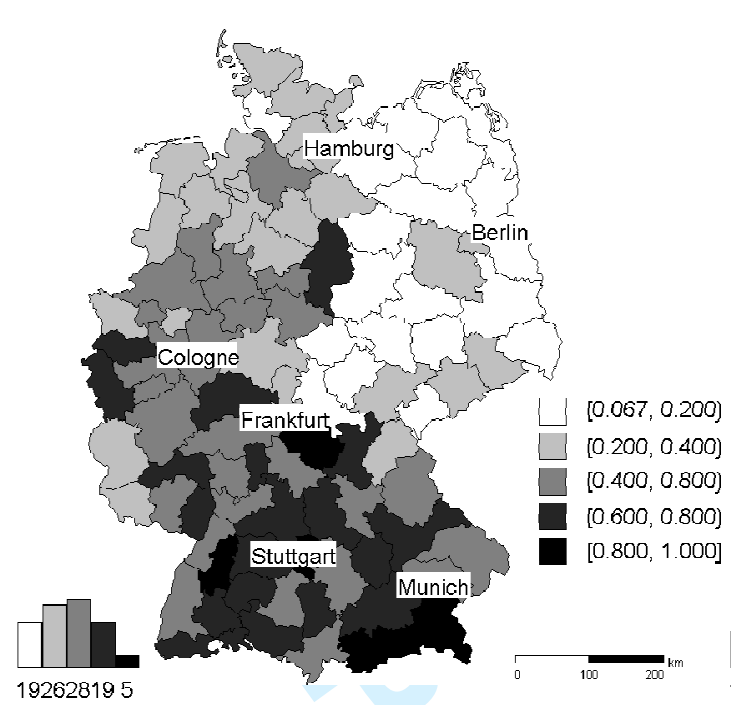

Efficiency of RIS (deterministic approach)

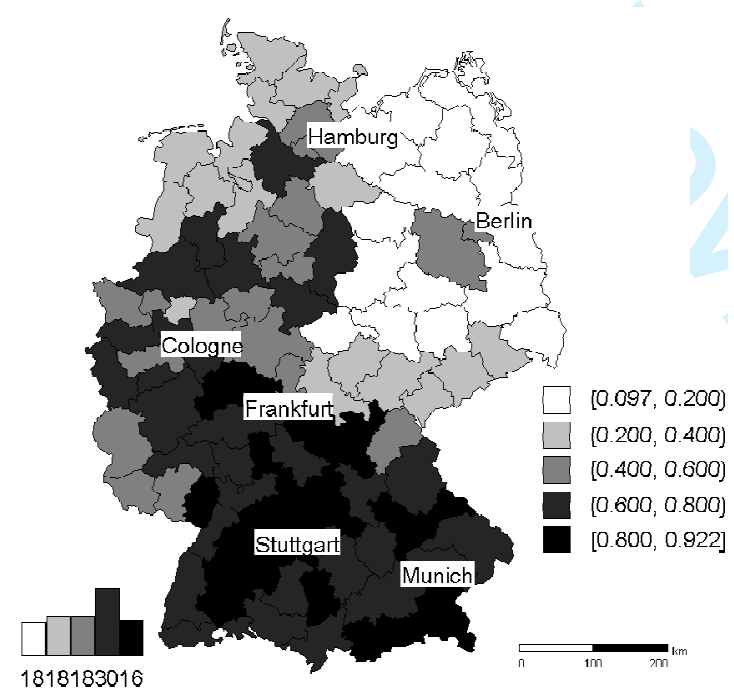

Efficiency of RIS (SFA, truncated normal)

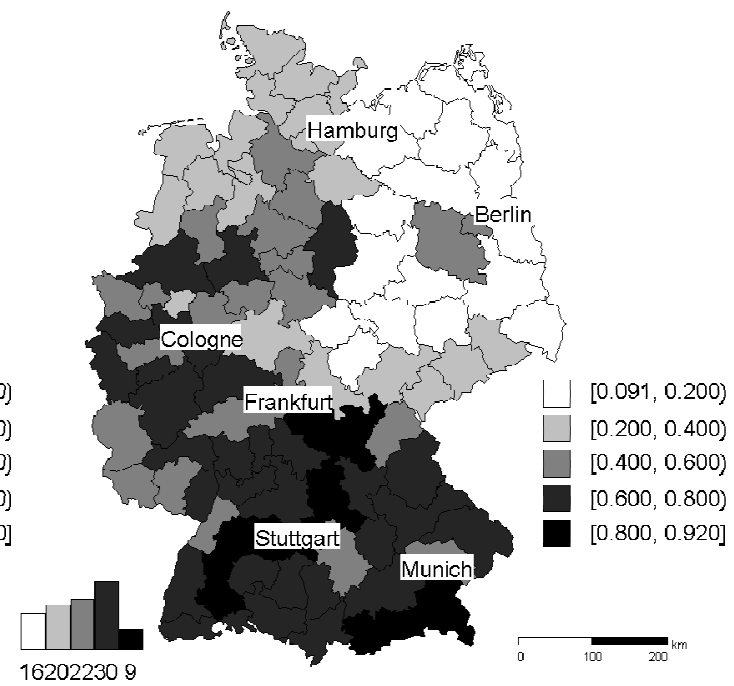

Efficiency of RIS (SFA, half-normal)

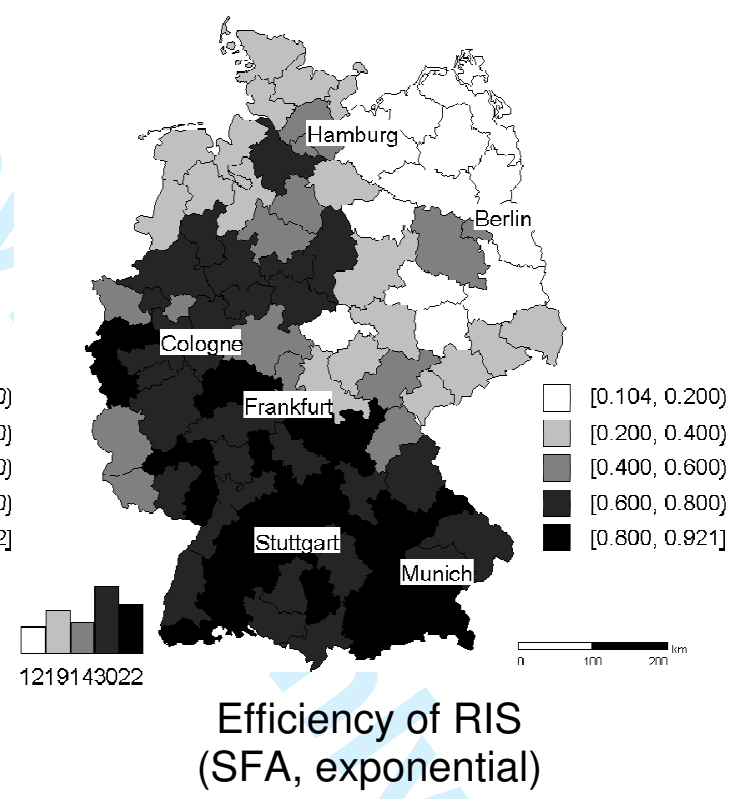

Figure 1: The spatial distribution of RIS efficiency in Germany 


\section{Appendix}

Table A1: Descriptive statistics of private sector R\&D output and input

\begin{tabular}{|c|c|c|c|c|c|}
\hline Variable & Mean & Median & Minimum & Maximum & Standard Deviation \\
\hline $\begin{array}{l}\text { PAT }_{\text {PRIV }} \\
\text { R\&D }\end{array}$ & $\begin{array}{r}291.465 \\
6674.016\end{array}$ & $\begin{array}{r}165.950 \\
3690000\end{array}$ & $\begin{array}{r}1.500 \\
649000\end{array}$ & $\begin{array}{r}3,143.322 \\
48\end{array}$ & $\begin{array}{r}408.519 \\
8724051\end{array}$ \\
\hline
\end{tabular}

Notes: Number of observations (regions) $=392$. 
Table A2: Correlation between variables

\begin{tabular}{|c|c|c|c|c|c|c|c|c|c|c|c|c|c|c|c|}
\hline No. Variable & 1 & 2 & 3 & 4 & 5 & 6 & 7 & 8 & 9 & 10 & 11 & 12 & 13 & $\overline{14}$ & 15 \\
\hline $1 \mathrm{TE}_{\mathrm{i}}^{\mathrm{DET}}[\ln ]$ & 1.000 & & & & & & & & & & & & & & \\
\hline $3 \mathrm{TE}_{\mathrm{i}}^{\mathrm{SFA}}$ (truncated normal) [In] & 0.996 & 0.999 & 1.000 & & & & & & & & & & & & \\
\hline $4 \mathrm{TE}_{\mathrm{i}}^{\mathrm{SFA}}$ (exponential) [In] & 0.993 & 0.998 & 0.999 & 1.000 & & & & & & & & & & & \\
\hline 6 TPF-PRIV [In] & 0.153 & 0.165 & 0.175 & 0.184 & 0.284 & 1.000 & & & & & & & & & \\
\hline $7 \mathrm{MPG}[\mathrm{In}]$ & 0.047 & 0.042 & 0.047 & 0.050 & 0.439 & 0.396 & 1.000 & & & & & & & & \\
\hline $8 \mathrm{FhG}[\mathrm{ln}]$ & 0.084 & 0.075 & 0.080 & 0.083 & 0.483 & 0.377 & 0.427 & 1.000 & & & & & & & \\
\hline 9 PROXTECH [In] & 0.473 & 0.471 & 0.475 & 0.478 & 0.296 & 0.340 & 0.265 & 0.271 & 1.000 & & & & & & \\
\hline 12 POPDEN [In] & 0.328 & 0.327 & 0.336 & 0.343 & 0.549 & 0.372 & 0.528 & 0.420 & 0.472 & 0.538 & 0.563 & 1.000 & & & \\
\hline 13 TRANSPORT [In] & 0.387 & 0.385 & 0.384 & 0.382 & 0.112 & 0.059 & -0.121 & -0.035 & 0.151 & -0.072 & 0.069 & 0.066 & 1.000 & & \\
\hline 14 ELECTRICAL [In] & 0.651 & 0.646 & 0.645 & 0.641 & 0.260 & 0.103 & 0.050 & 0.124 & 0.429 & -0.053 & 0.163 & 0.262 & 0.229 & 1.000 & \\
\hline 15 OPTICS [In] & 0.453 & 0.438 & 0.432 & 0.425 & 0.097 & -0.013 & 0.072 & -0.030 & 0.309 & -0.059 & -0.142 & 0.049 & 0.090 & 0.415 & 1.000 \\
\hline 16 CHEMISTRY [In] & 0.465 & 0.468 & 0.473 & 0.476 & 0.351 & 0.149 & 0.237 & 0.151 & 0.220 & 0.344 & 0.066 & 0.421 & 0.075 & 0.157 & 0.169 \\
\hline
\end{tabular}




\title{
Notes
}

\begin{abstract}
1. A regional innovation system is commonly understood as a set of all those local actors, formal institutions, and other organizations that jointly or individually contribute to the generation, use, accumulation, and diffusion of knowledge and technologies (ASHEIM and GERTLER, 2005; COOKE, URANGA and ETXEBARRIA, 1997).
\end{abstract}

2. This classification is provided by the World Intellectual Property Organization (WIPO).

3. Patent applications by private companies account, on the average, for about three-quarters of all patent applications.

4. If a patent has more than one inventor, the count is divided by the number of the inventors involved and that fraction assigned to each inventor's region of residence. Hence, the number of regional patents may not always be a whole number.

5. For example, COHEN, NeLSON and WALSH (2002) as well as SCHARTINGER, SCHIBANY and GASSLER (2001) provide evidence for the 
greater importance of cooperations and informal university-industry linkages (e.g., information trading) as compared to channels of knowledge transfer such as licenses, prototypes, etc.

6. Assuming such a time lag also helps avoid potential problems of endogeneity between R\&D inputs and output. FRITSCH and SLAVTCHEV (2007, 2008), in their analysis for Germany, use a time lag of three years between patent applications and innovative input. FISCHER and VARGA (2003) use a two-year lag and RONDE and HUSSLER (2005) link the number of patents between 1997 and 2000 to R\&D efforts in 1997. ACS, ANSELIN and VARGA (2002) report that U.S. innovation records in 1982 result from inventions made 4.3 years prior.

7. BODE (2004) also uses a time lag of one year when relating patent output to R\&D employment across German planning regions.

\footnotetext{
8. For this definition of the planning regions, see Federal Office for Building and Regional Planning (BUNDESAMT FUER BAUWESEN UND RAUMORDNUNG - BBR, 2003).
} 
9. Hence, there is the danger that an extremely high output value that is due to stochastic disturbances is mistaken as the benchmark for the measurement of efficiency.

10. Arora and Gambardella $(1994,1998)$; Arora, Gambardella and Rullani (1997); CockBuRn Et AL. (1999); ARORA, FosfurI and GAMBARDELLA (2001).

11. The existence of such a positive impact of interaction and exchange between regional actors on innovation activity is a main hypothesis in the literature on industrial districts (cf. PORTER, 1998; PYKE, BECCATINI and SENGENBERGER, 1990), innovation networks (cf. CAMAGNI, 1991; GRABHER, 1993), and "innovative milieux" (CREVOISIER, 2004; RATTI, BRAMANTI and GORDON, 1997). In this literature, it is argued that regional differences in interaction behavior are responsible to a considerable degree for differences with regard to innovation activity, particularly the efficiency of R\&D. One main reason given for such a positive effect is that the interaction between actors may work as an important medium for knowledge spillovers. Knowledge spillovers play a significant role in recent approaches to growth theory (cf. KRUGMAN, 1991; ROMER, 1994), as well as in the concept of (national or 
regional) innovation systems (cf. LUNDVALL, 1992; NELSON, 1993; EDQUIST, 1997; CoOke, Uranga and EtXebarRia, 1997).

12. Based on a survey of about 2,300 private enterprises in Germany, BEISE and STAHL (1999) found that about 60 percent of the firms that had introduced university-based innovations were located at a distance of up to $100 \mathrm{~km}$ from the particular knowledge source. When technical colleges were the source of knowledge, the figure was about 80 percent. Similar finding are provided by econometric studies on the spatial scope of university-industry linkages. By using third-party funds from private firms as an indicator for university-industry linkages, FRITSCH and SLAVTCHEV $(2007,2008)$ found spillovers from universities at a distance of up to $50 \mathrm{~km}$. Because most universities in Germany are located in relatively large cities, which are usually also considered the core city of their planning region, these results suggest that, for the most part, both university-private sector cooperation partners will be located in the same planning region.

13. See GreIF and SCHMiedL (2002) for a definition of the 31 technological fields. 
14. In the period 1995-2000, about 9.6 percent of all patent applications were submitted in the field of transportation engineering, 13 percent in electrical engineering, and 7.4 percent in measurement engineering/optics (GREIF and SCHMIEDL, 2002).

15. The results for the truncated normal distribution and the exponential distribution differ only slightly from those for the half-normal distribution and are, therefore, not reported here.

16. The variable for the third-party funds from the private sector per university professor (TPF-PRIV) has been excluded here due to multicollinearity problems when the number of Max Planck (MPG) and Fraunhofer institutes (FhG) are included in the model.

17. When the impact of PROXTECH is analyzed, TPF-PRIV, MPG, and FhG are excluded from the model because PROXTECH measures the potential knowledge spillovers between all types of public research institutions and the private sector. Hence, the effects of universities and institutes of the Max-Planck or Fraunhofer-Society are already included. 
18. Two sample mean comparison test suggests significantly less industrial diversity in East Germany (1.404) than in West Germany (1.527). 


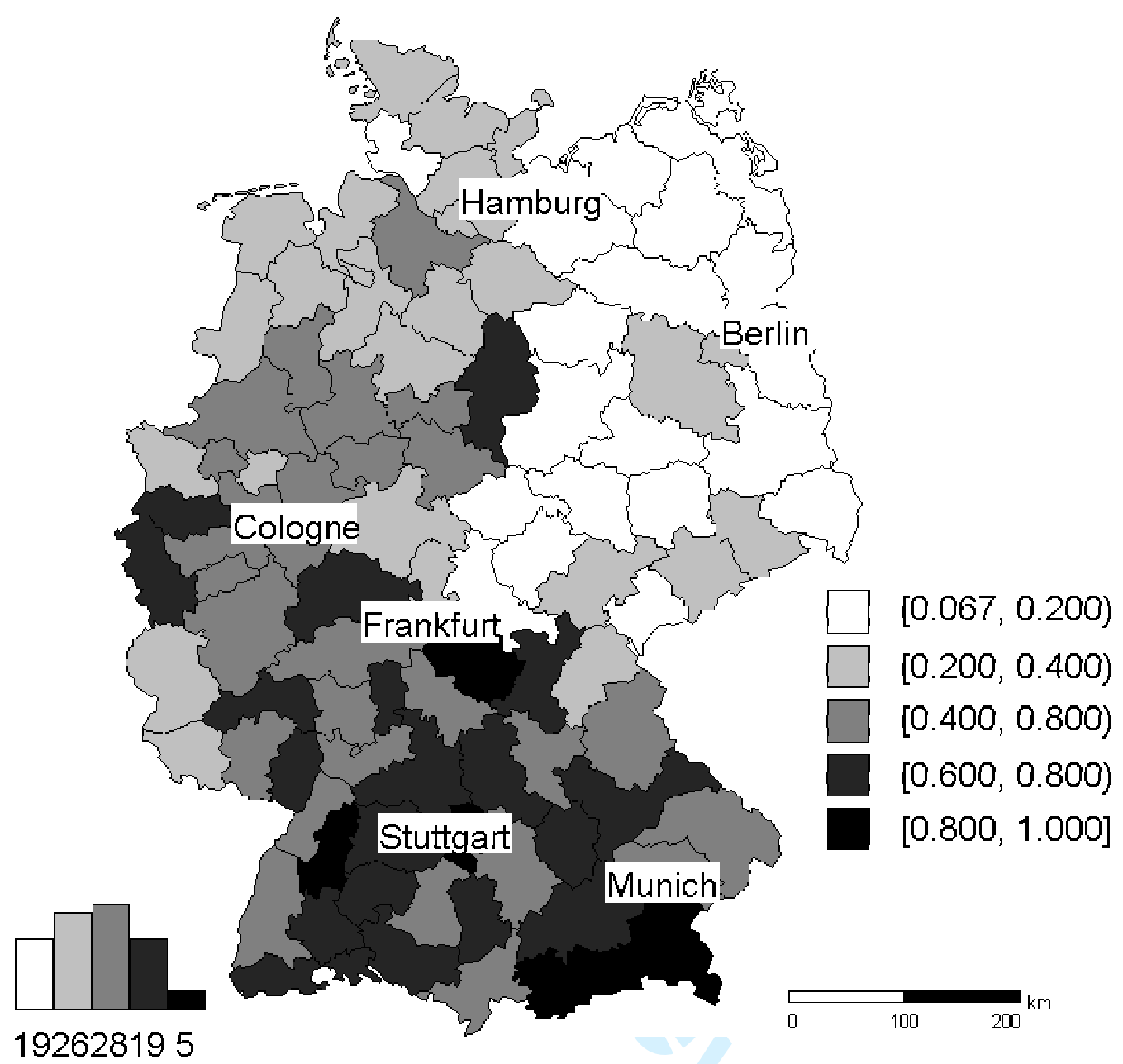

RIS efficiency deterministic approach (file name: te_det_tif) 


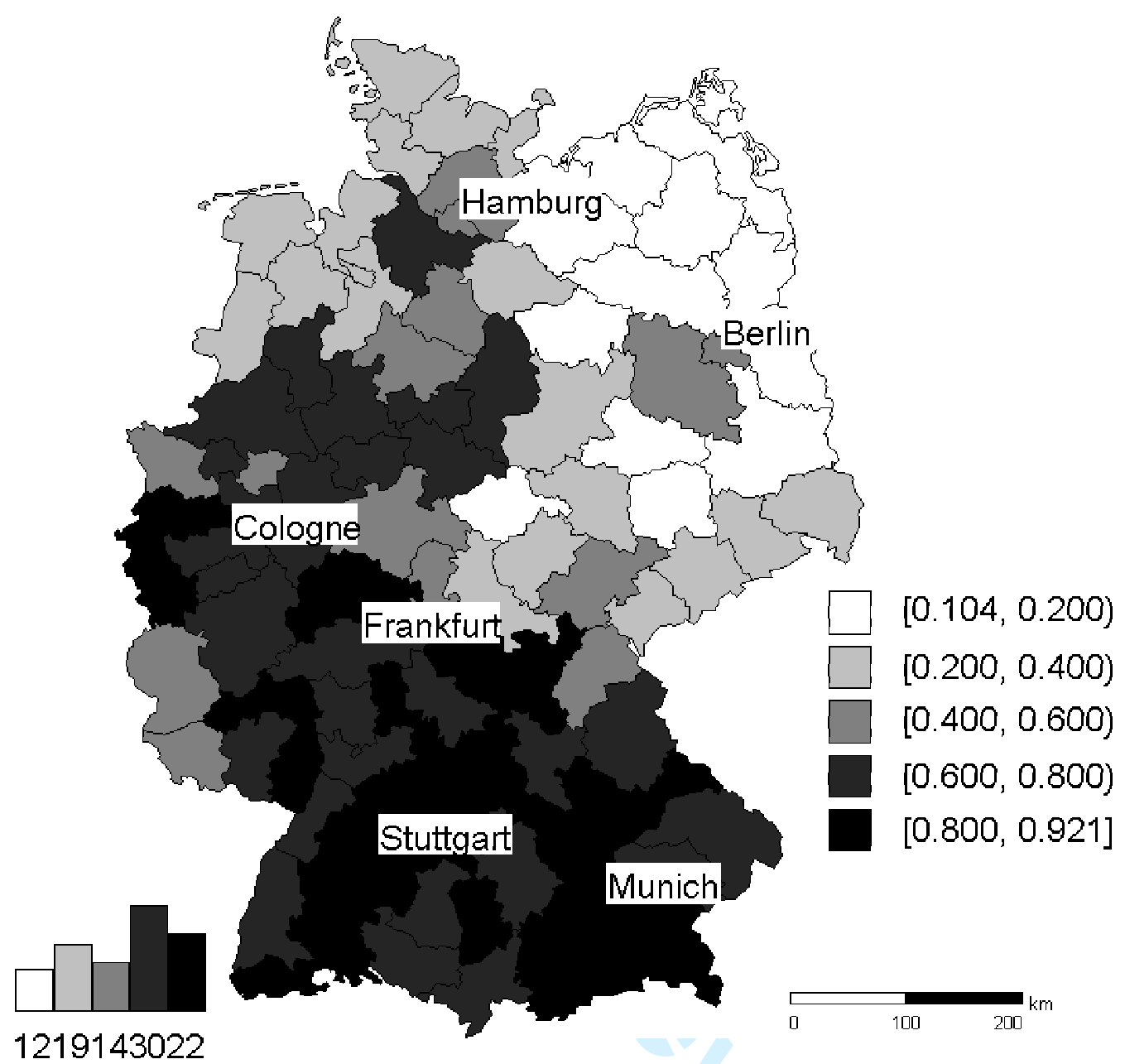

RIS efficiency stochastic frontier approach with exponential distributed efficiency term (file name: te_sfae_tif) 


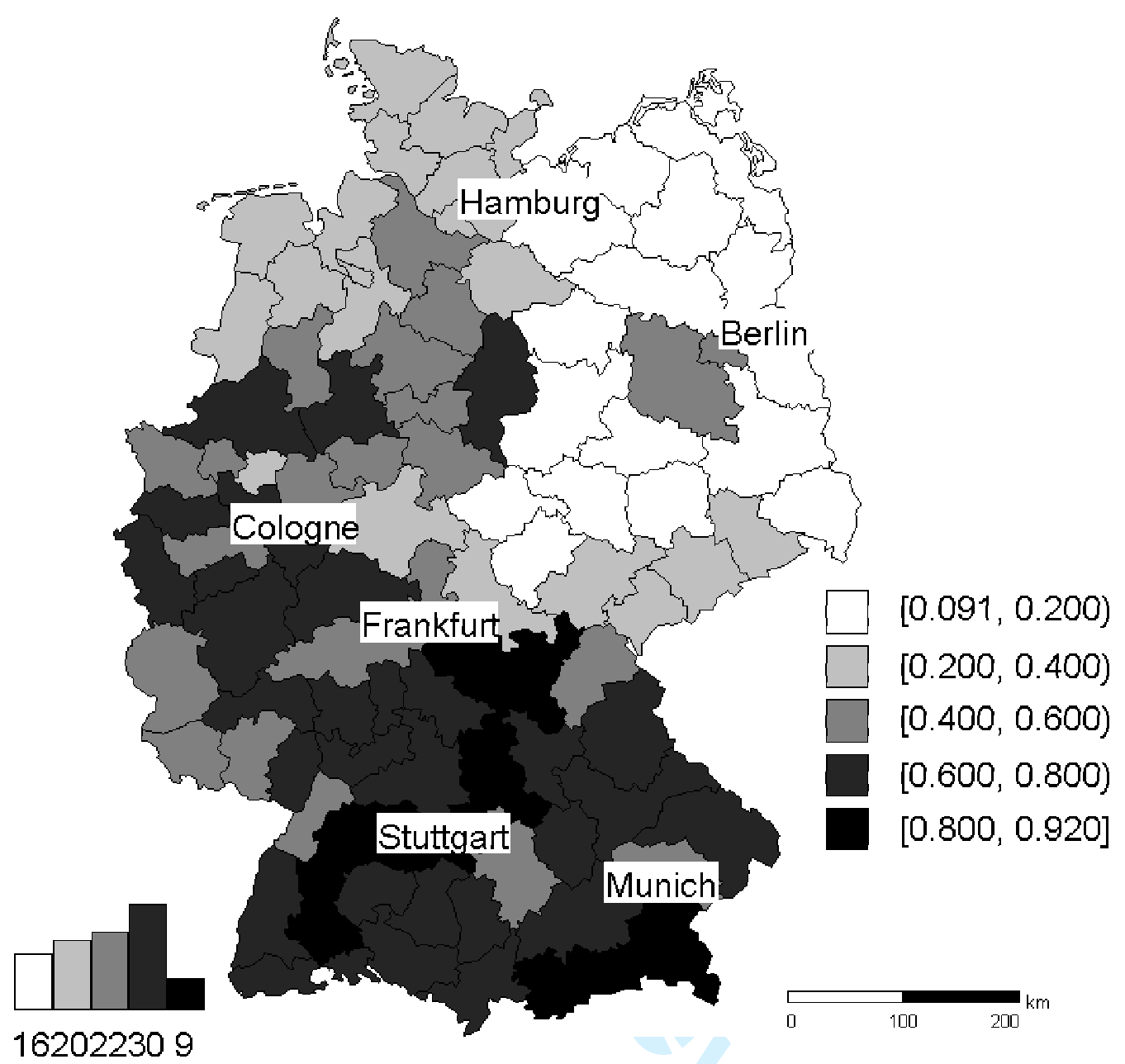

RIS efficiency stochastic frontier approach with half-normal distributed efficiency term (file name: te_sfah_.tif) 


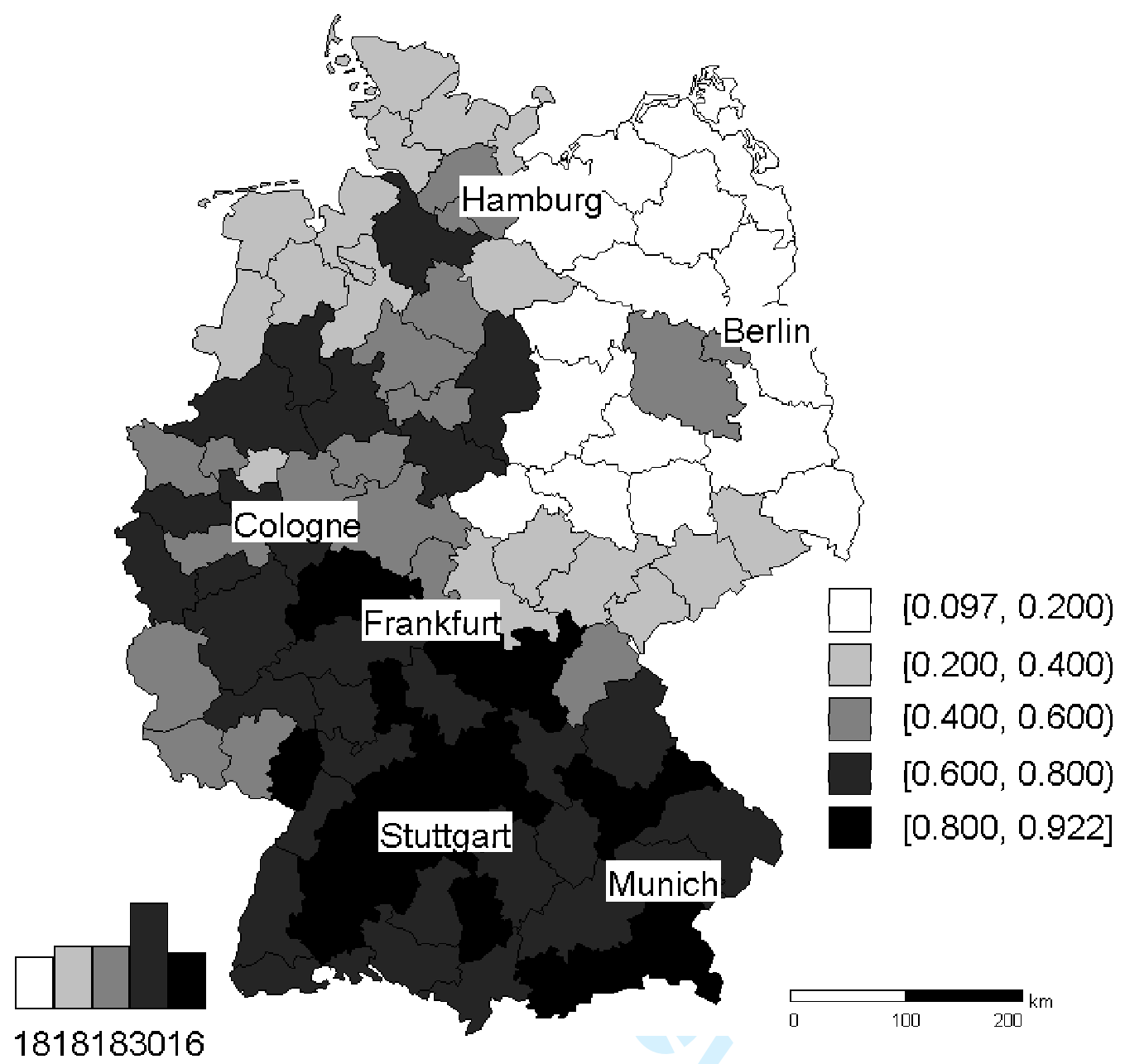

RIS efficiency stochastic frontier approach with truncated-normal distributed efficiency term (file name: te_sfat_tif) 


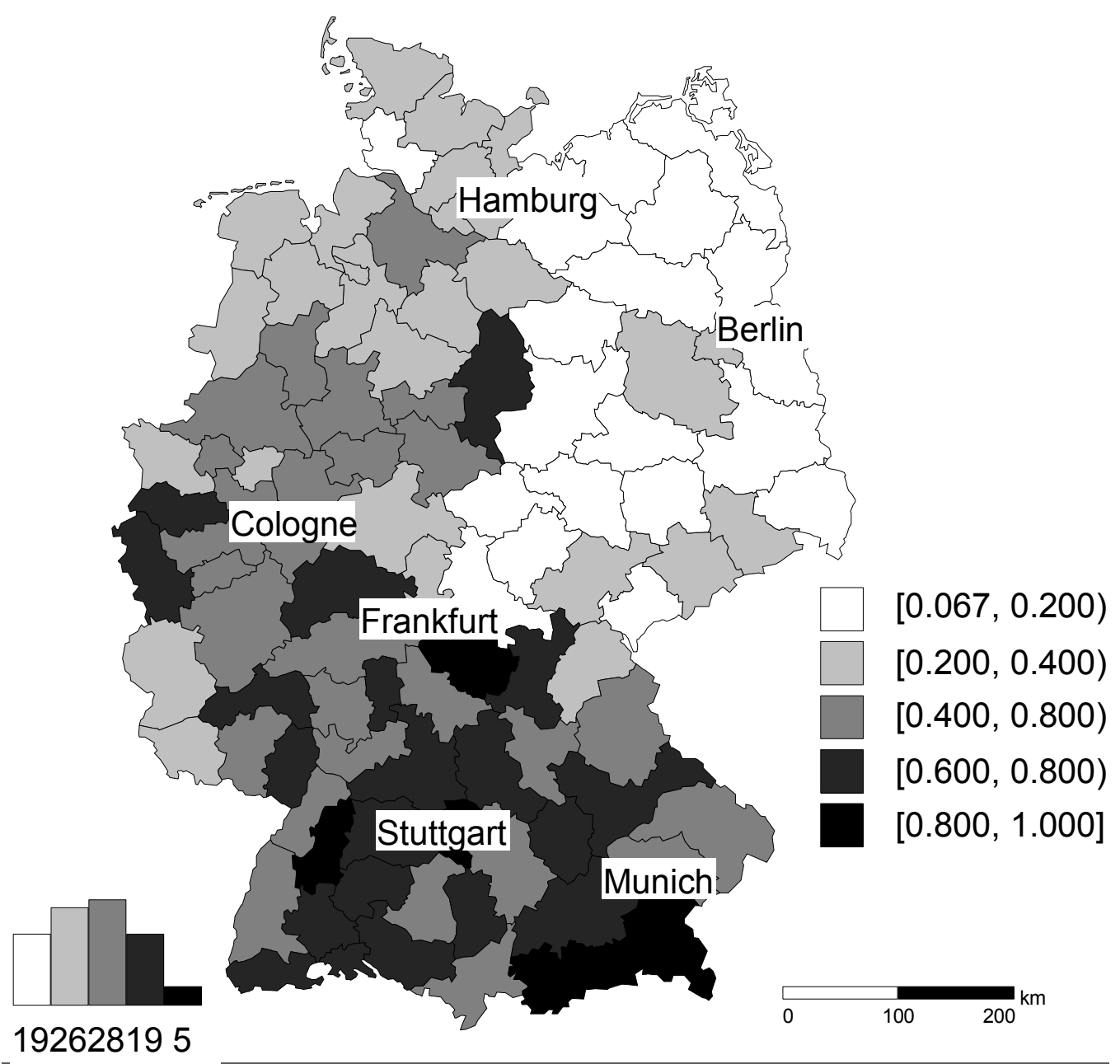

RIS efficiency deterministic approach (file name: te_det_wmf) 


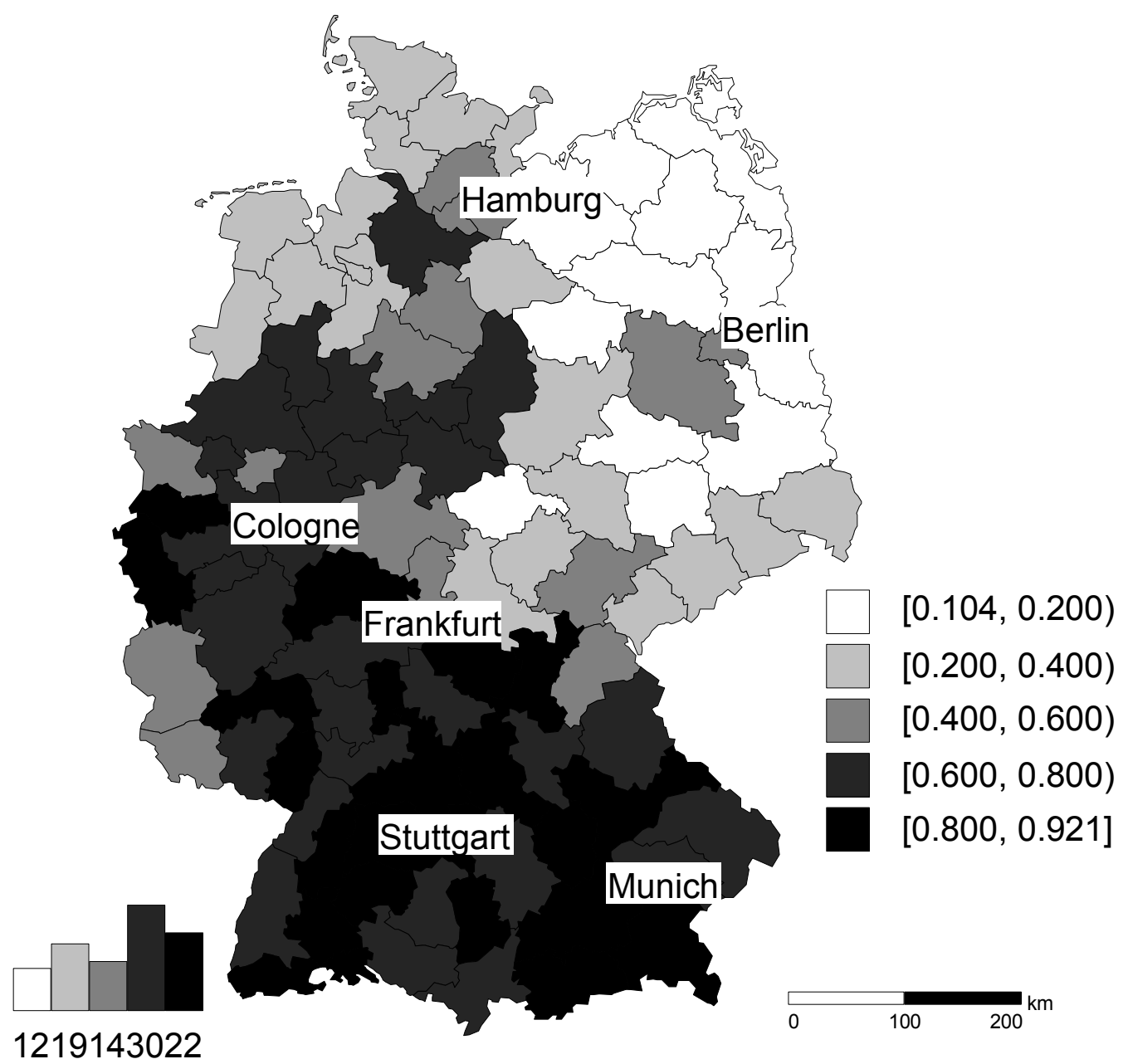

RIS efficiency stochastic frontier approach with exponential distributed efficiency term (file name: te_sfae_.wmf) 


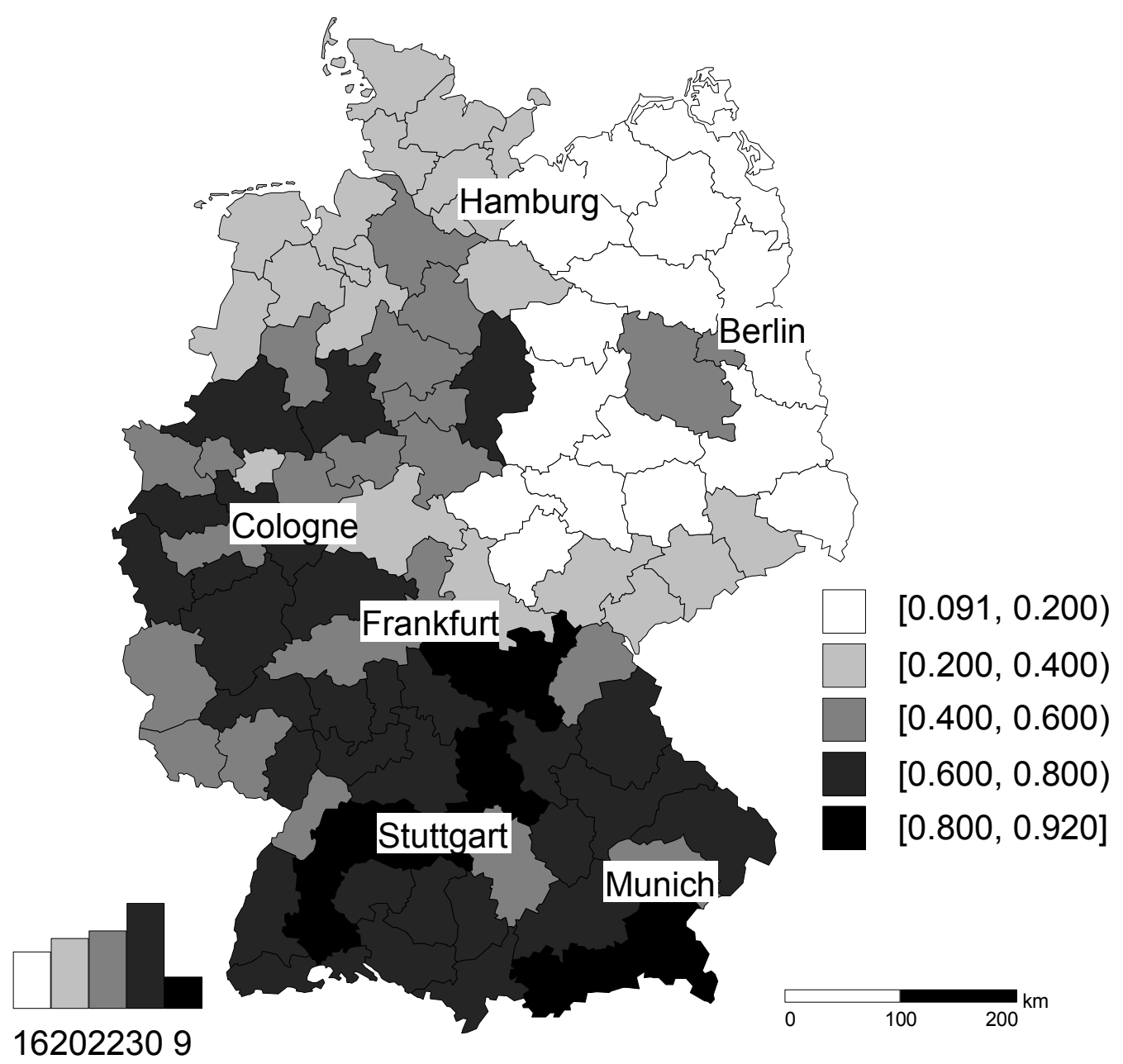

RIS efficiency stochastic frontier approach with half-normal distributed efficiency term (file name: te_sfah_.wmf) 


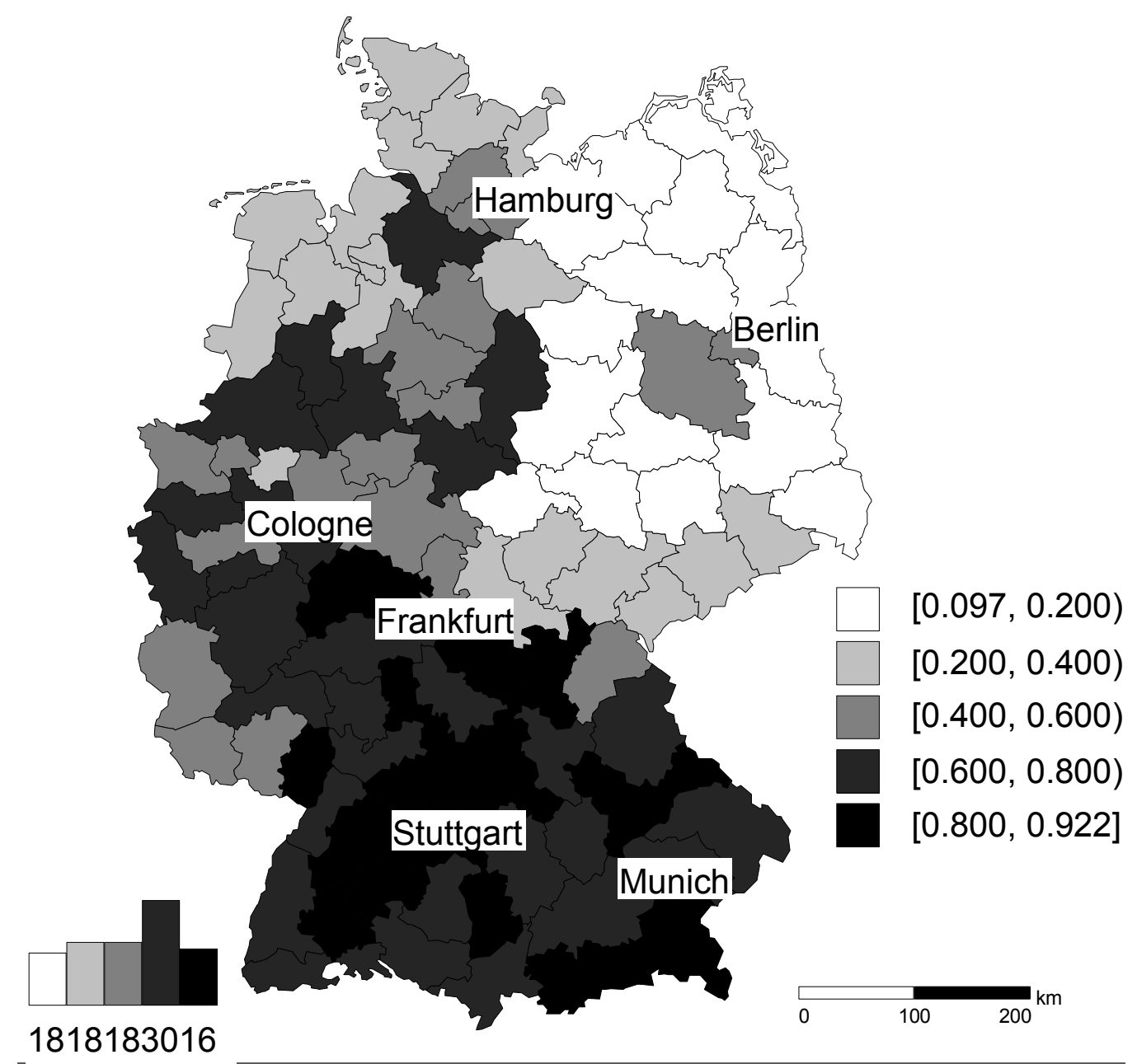

RIS efficiency stochastic frontier approach with truncated-normal distributed efficiency term (file name: te_sfat_.wmf) 